\title{
Personnel Exposure to Scattered Radiation during Radiography of the Distal Interphalangeal Joint in the Horse Using a Portable X-ray Machine
}

\author{
J. ŠTERC, R. LEPKOVÁ \\ University of Veterinary and Pharmaceutical Sciences, Brno \\ Received February 27, 2006 \\ Accepted September 5, 2006
}

\begin{abstract}
Šterc J., R. Lepková: Personnel Exposure to Scattered Radiation during Radiography of the Distal Interphalangeal Joint in the Horse Using a Portable X-ray Machine. Acta Vet Brno 2007, 76: 105-111.

Radiography of the distal interphalangeal joints of two limbs of a cadaver of a horse weighing $550 \mathrm{~kg}$ was conducted in the present study. The examination was performed on lateromedial, palmaroproximal-palmarodistal views and on dorsoproximal-palmarodistal, dorsolateralpalmaromedial, dorsomedial-palmarolateral views of a raised limb placed on a navicular block, and of weight-bearing limbs. During the examination, doses of scattered radiation were measured at the sites of radiographer, assistant holding a film cassette and assistant positioning the examined limb or the opposite one. The lowest radiation dose was received by the assistant holding the cassette behind the examined region; a total equivalent dose of $183.6-201.7 \mathrm{nSv}$ was received by his hands and genitals, and $110.8-113.3 \mathrm{nSv}$ by his eye lens and neck during the examination of the distal interphalangeal joint. The radiographer was exposed to higher radiation; an equivalent dose of 846.6 - 854.1 nSv was received by his hands and genitals, and $271.8-328.2 \mathrm{nSv}$ by the eye lens and the neck. The highest scattered radiation dose was received by the assistant positioning the examined limbs; equivalent doses were 7751 - $9354 \mathrm{nSv}$ (hands), 1117.3 - $1119.5 \mathrm{nSv}$ (genitals), and 880.6 - $1096.2 \mathrm{nSv}$ (eye lens and neck). The equivalent dose values measured, received by the radiographer and the assistants during the examination of the distal interphalangeal joint seem to be very low relative to radiation exposure limits. However, it must be taken into account that the personnel involved in radiography is also exposed to scattered radiation during other examinations where radiation doses are often much higher. These results indicate the necessity to use protective lead aprons, gloves and collars during radiography of the distal interphalangeal joint.
\end{abstract}

Radiation exposure, radiation dosage, pre-purchase examination, radiological examination, scatter radiation

Radiography of the distal interphalangeal joint in the horse is performed as part of the lameness diagnosis and usually follows the clinical examination of the affected limb (Kawcak 2001; Stashak 2002).

Radiography plays a significant role in the pre-purchase examination of the distal interphalangeal joint because it can reveal discrete osteoarthritic changes with no apparent clinical signs; these may induce lameness in the horse in the future, and result in a legal dispute between the seller and the buyer (Lauk 2002; Ueltshi 2002). These researchers claim it is necessary to perform radiography of the joint on lateromedial (LM) view, dorsoproximal-palmarodistal (DP-PD) view, dorsolateral-palmaromedial (DL- PM) view, dorsomedial-palmarolateral (DM-PL) view and palmaroproximal-palmarodistal (PP-PD) view. DP-PD, DL-PM and DM-PL are usually performed on a raised limb placed on a navicular block (Butler et al. 2000). These views will be further designated as DP-PDup, DL-PMup and DL-PMup When these views are performed, one assistant positions the examined limb on a navicular block. It is also possible to perform these views on a weightbearing limb, placed on a pedestal designed for this purpose (Crháková and Šterc 2003). These views will be further designated as DP-PDhc, DL-PMhc, DM-PLhc. Taking these

Address for correspondence:

MVDr. Jan Šterc, PhD

Křídlovická 16

60300 Brno

Czech Republic

Phone: +420608969578

E-mail: stercj@cervus.cz

http://www.vfu.cz/acta-vet/actavet.htm 
views, the assistant does not perform positioning of the examined limb, but restrains the horse by raising the contralateral limb. Hence, radiography requires the presence of not only a radiographer, but also of assistants who restrain the examined horse and hold the cassette containing an X-ray film behind the examined region. The cassette is usually attached to a handle with an adequately long grip, thereby reducing the assistant's exposure to scattered radiation (Morgan 1991; Lavin 1999).

The radiographer and assisting personnel are not exposed to the primary beam, but to scattered radiation produced by interactions between the primary beam and objects in its path, i.e. the examined region and cassette (Lavin 1999). Therefore, the appropriate ionizing radiation safety precautions must be observed. The protection of personnel exposed to radiation during radiography is a special case of protection of personnel working with ionizing radiation sources, and conforms to the rules of radiation safety system. The aim of protection of personnel involved in radiodiagnosis is to eliminate deterministic (non-stochastic) effects, and to reduce potential development of stochastic effects to the level acceptable for both individuals and general public (ICRP publication 60: 1990).

The reduction in staff irradiation is ensured by establishing and maintaining a radiation safety programme, apart from other measures. The limits are obligatory quantitative parameters of total irradiation from radiography, and their exceeding is not acceptable in specified cases. There are several types of irradiation limit: dose limits for the public, dose limits for the exposed workers, and dose limits for apprentices and students at the age of 16 to 18 . For the public, the limit of equivalent dose received by the eye lens has been set at $15 \mathrm{mSv}$ per calendar year, and the limit of average equivalent dose per $1 \mathrm{~cm}^{2}$ of skin $50 \mathrm{mSv}$ per calendar year. For the exposed workers, the established limit of equivalent dose received by the eye lens is $150 \mathrm{mSv}$ per calendar year, the limit of average equivalent dose per $1 \mathrm{~cm}^{2}$ of skin is $500 \mathrm{mSv}$ per calendar year, and the limit of equivalent dose to the hands from fingers to forearm, and to the legs from sole to ankle is $500 \mathrm{mSv}$ per calendar year. The equivalent dose for apprentices and students at the age of 16 to 18 to the lens of the eye is $50 \mathrm{mSv}$ per calendar year, the limit of average equivalent dose per $1 \mathrm{~cm}^{2}$ of skin is $150 \mathrm{mSv}$ per calendar year, and the limit of equivalent dose to hands from fingers up to the forearm and to legs from the sole to the ankles as $150 \mathrm{mSv}$ per calendar year (Council Directive 96/29/Euratom of 13 May 1996; Vyhláška 307/2002 Sb.).

The aim of the present study, similar to that by Nolker and Uelts chi (2001) carried out with small animals, was:

- To measure scattered radiation doses received by the radiographer and the assisting personnel during the examination of distal interphalangeal joint on LM, PP-PD and DP-PDup, DL-PMup and DL-PMup views, and to compare the radiation doses received.

- To measure scattered radiation doses received by the radiographer and the assisting personnel during the examination of distal interphalangeal joint on LM, PP-PD and DP-PDhc, DL-PMhc, DM-PLhc views and to compare the radiation doses received.

- To compare scattered radiation doses received by individuals during the examination of distal interphalangeal joint on LM, PP-PD and DP-PDup, DL-PMup and DL-PMup views with scattered radiation doses received by the same individuals during the examination of distal interphalangeal joint on LM, PP-PD and DP-PDhc, DL-PMhc, DM-PLhc views.

- To compare the doses measured with the above-mentioned irradiation limits.

\section{Materials and Methods}

For the detection of the exposure of respective persons to scattered radiation, two frozen forelimbs of a horse cadaver weighing about $550 \mathrm{~kg}$ were used. Before freezing, one limb was placed in a position allowing radiological examination of the distal interphalangeal joint on LM, PP-PD views and DP-PDhc, DL-PMhc, DM-PLhc views later on (i.e. on weight bearing limb placed on a pedestal constructed for this purpose). The other limb was placed 
in the position allowing radiological examination of the distal interphalangeal joint on DP-PDup, DL-PMup and DL-PMup views later on (i.e. in the limb positioned on a navicular block). Radiological examination of the distal interphalangeal joint on the above-mentioned views was performed later. Doses of scattered radiation at the sites of radiographer and assisting personnel were measured during the examination. During all the examinations, the limb was placed on a flat block or navicular block, and positioned as required by the respective views. A cassette of $24 \times 30 \mathrm{~cm}$, attached to a cassette holder, was placed behind the examined region. When the distal interphalangeal joint was examined on DP-PDup and DP-PDhc views, a cassette with a grid was located behind the examined region. The irradiated region was made as wide as possible, but it did not overlap the cassette edges. The radiographic examination was performed, using the portable X-ray machine Gierth HF 80 plus, placed on an original tripod. Eight days before the measurement, a test of long term stability of the X-ray machine was performed; the test results showed that the machine parameters complied with standards, and reproducibility of exposure was satisfactory. The dosimeter Radcal 9010 with a $1000 \mathrm{~cm}^{3}$ ionization chamber, or an ionization chamber of $100 \mathrm{~cm}^{2}$ section area, were used to measure scattered radiation. The apparatus was assigned for this measurement, and a valid certification on the apparatus verification was provided.

Measurements were conducted in the examination room at our clinic. The walls and floor were protected against ionizing radiation as required by regulations. The floor of the examination room was covered with $70 \times 70 \mathrm{~cm}$ rubber squares. The rubber paving served as a coordinate frame to locate the ionisation chamber in an adequate distance from the screened limb. The elevation of the X-ray machine above the floor level, focal distance (FFD), direction of the primary beam, exposure values and distances between the radiographer, assistants and the examined limb during the screening of the distal interphalangeal joint on respective views is shown in Table 1.

Table 1. Conditions of the measurement of scattered radiation exposure by the personnel during the radiological examination of distal interphalangeal joint

\begin{tabular}{|l|c|c|c|c|c|c|c|c|}
\hline & \multirow{2}{*}{$\begin{array}{c}\text { X-ray } \\
\text { View }\end{array}$} & \multirow{2}{*}{$\begin{array}{c}\text { FFD } \\
\text { elevation } \\
(\mathrm{cm})\end{array}$} & \multirow{2}{*}{$\begin{array}{l}\text { Primary beam } \\
\text { direction }\end{array}$} & & \multicolumn{2}{|c|}{ Exposure values } & \multicolumn{3}{|c|}{ Distance of persons from limb } \\
\cline { 5 - 10 } & & & $\mathrm{kV}$ & $\mathrm{mAs}$ & radiographer & $\begin{array}{c}\text { assistant } \\
\text { (cassette) }\end{array}$ & $\begin{array}{c}\text { assistant } \\
\text { (limb) }\end{array}$ \\
\hline LM & 10 & 70 & horizontal & 70 & 0.9 & 100 & 90 & 70 \\
\hline PP-PD & 50 & 60 & $55^{\circ}$ & 80 & 0.9 & 50 & $\mathrm{x}$ & aside \\
\hline DP-PDup & 20 & 100 & horizontal & 80 & 1.8 & 130 & $\mathrm{x}$ & aside \\
\hline DL-PMup & 20 & 70 & horizontal & 65 & 0.9 & 100 & 90 & aside \\
\hline DM-PLup & 20 & 70 & horizontal & 65 & 0.9 & 100 & 90 & aside \\
\hline DP-PDhc & 60 & 100 & $45^{\circ}$ & 80 & 1.8 & 100 & $\mathrm{x}$ & 50 \\
\hline DL-PMhc & 50 & 70 & $45^{\circ}$ & 65 & 0.9 & 100 & 90 & 50 \\
\hline DM-PLhc & 50 & 70 & $45^{\circ}$ & 65 & 0.9 & 100 & 90 & 50 \\
\hline
\end{tabular}

The positions of radiographer and assisting personnel during radiography of the distal interphalangeal joint on respective views are shown in Figs 1 - 10 (Plates VIII, IX, X and XI).

Scattered radiation was measured at the site of radiographer, behind the X-ray machine, and at the site of the assistant holding the cassette attached to the holder during all examinations. Measurements at a height of $90 \mathrm{~cm}$ (the level of genitals and hands) and at a height of $160 \mathrm{~cm}$ (the level of neck and head) were made at both the sites. Scattered radiation was also measured at the site of the assistant holding the horse's limb. Measurements at heights of 90 and $160 \mathrm{~cm}$ were performed during radiological examinations on the views where the assistant restrained the horse by raising the contralateral limb (i.e. LM, DP-PDhc, DL-PMhc and DM-PLhc views). During the examination on DP-PDup, DL-PMup, DM-PLup views (i.e. on the limb placed on the navicular block), the measurements of the examined limb at the distal end of the forearm above the carpus at a height of $90 \mathrm{~cm}$ (the usual level of hand, neck and head of the assistant positioning of the limb), and at the dorsal aspect of metacarpus (usual position of the other hand of the assistant) were performed. During the radiological examination of the distal interphalangeal joint on PP-PD view, when the assistant positioned the limb placed on a pedestal with a cassette, scattered radiation at the posterior caudal aspect of forearm at a height of $90 \mathrm{~cm}$ above the floor (usual position of neck and head of assistant performing positioning of this limb) and at the palmar aspect of metacarpus (usual position of the hand of assistant) were measured. During the measurement of scattered radiation, doses at the measurement points at the place where the assistant positioning the limb was located were measured, the option that a part of the assistant's body is shielded by the body of the horse was not taken into consideration. The positions of the X-ray machine, examined limb and measurement points during the radiological examination of distal interphalangeal joint on respective views are shown in Figs. 1 - 8. Doses of scattered radiation at different measurement points were always measured in 3 successive exposures. In some examinations, repeated measurements were performed to test reproducibility of the exposure. A pause of $40 \mathrm{~s}$ was made between exposures because the X-ray machine was not designed for such a high exposure frequency. We considered the risk of damage 
to the apparatus or disproportions in reproducibility of exposures. The background was measured five times altogether, at the beginning, during the measurement, and at the end of measurement, with the duration of measurement ranging from 5 to 45 minutes.

In order to compare scattered radiation doses measured at different points of measurements at the site of the radiographer and both assistants with radiation limits, and to compare the exposure doses received by these people, we assumed that:

Doses at the measurement point $90 \mathrm{~cm}$ above the floor level, at the sites of radiographer and assistant holding the cassette during all views corresponded with equivalent doses received by their genitals and hands.

Doses at the measurement point $160 \mathrm{~cm}$ above the floor level, at the sites of radiographer and assistant holding the cassette during all views corresponded with equivalent doses received by their thyroid gland and eye lens.

In order to compare the potential measured doses of scattered radiation at respective measurement points at the site of the assistant holding the cassette, we assumed that:

Doses at the measurement point $90 \mathrm{~cm}$ above the floor level at the site of the assistant positioning the contralateral limb on LM view and DP-PDhc, DL-PMhc and DM-PLhc views corresponded with equivalent doses received by this assistant's genitals and hands.

Doses at the measurement point $160 \mathrm{~cm}$ above the floor level at the site of the assistant positioning the contralteral limb on LM view and on DP-PDhc, DL-PMhc and DM-PLhc views corresponded with equivalent doses received by the assistant's thyroid gland and eye lens.

Doses at the measurement point $90 \mathrm{~cm}$ above the floor level at the site of the assistant positioning the limb on PP-PD view corresponded with equivalent doses received by the assistant's genitals, thyroid gland and eye lens.

A dose at the measurement point at the palmar aspect in the middle of metacarpus of the measured limb on PP-PD view corresponded with equivalent doses received by the assistant's hand.

Doses at the measurement point $90 \mathrm{~cm}$ above the floor level at the site of the assistant positioning the limb on DP-PDup, DL-PMup and DM-PLup views corresponded with equivalent doses received by the assistant's genitals, thyroid gland and eye lens.

Doses at the measurement point at the dorsal aspect in the middle of metacarpus of the examined limb on DP-PDup, DL-PMup and DM-PLup views corresponded with equivalent doses received by the assistant's hands.

Equivalent doses received by the personnel's hands, genitals, eye lens and neck, measured at the sites of radiographer, assistant holding the cassette and assistant positioning the limb, were derived from average doses of scattered radiation obtained by measurements in respective views at the above mentioned points. An average value was calculated from these scattered radiation doses received by the radiographer and assistants to hands, genitals, eye lens and neck; the value was regarded as an approximate equivalent dose per $1 \mathrm{~cm}^{2}$ of skin.

The comparison of scattered radiation exposure of the radiographer and the assisting personnel during the X-ray examination of the distal interphalangeal joint was performed using the Steel-Daass test. The comparison of scattered radiation exposure of the assisting personnel during X-ray examination of the distal interphalangeal joint on LM, PP-PD and DP-PDup, DL-PMup and DM-PLup views with scattered radiation exposure of these people during X-ray examination of the distal interphalangeal joint on LM, PP-PD and DP-PDhc, DL-PMhc, DM-PLhc views was also performed using the Steel-Daass test.

\section{Results}

Table 2. Scattered radiation doses (in $\mathrm{nSv}$ ) received by the radiographer and assistants on respective views

\begin{tabular}{|c|c|c|c|c|c|c|c|}
\hline \multirow[b]{2}{*}{ View } & \multicolumn{2}{|c|}{ Radiographer } & \multicolumn{2}{|c|}{ Assistant - cassette } & \multicolumn{3}{|c|}{ Assistant - limb } \\
\hline & $\begin{array}{l}\text { hands } \\
\text { genitals }\end{array}$ & $\begin{array}{c}\text { eye lens, } \\
\text { neck }\end{array}$ & $\begin{array}{l}\text { hands } \\
\text { genitals }\end{array}$ & $\begin{array}{c}\text { eye lens, } \\
\text { neck }\end{array}$ & hands & genitals & $\begin{array}{c}\text { eye lens, } \\
\text { neck }\end{array}$ \\
\hline LM & 62.5 & 42.1 & 57.7 & 32.1 & 46.1 & 46.1 & 25.0 \\
\hline PP-PD & 488.1 & 101.4 & & & 7267.3 & 635.8 & 635.8 \\
\hline DP-PDup & 93.3 & 63.6 & & & 1366.7 & 168.3 & 168.3 \\
\hline DL-PMup & 105.7 & 63.7 & 69.5 & 40.0 & 390.1 & 144.0 & 144.0 \\
\hline DM-PLup & 97.0 & 57.4 & 74.5 & 41.2 & 283.8 & 123.1 & 123.1 \\
\hline DP-PDhc & 173.7 & 65.0 & & & 232.1 & 232.1 & 120.3 \\
\hline DL-PMhc & 52.3 & 25.0 & 57.2 & 34.1 & 81.2 & 81.2 & 39.5 \\
\hline DM-PLhc & 77.5 & 38.3 & 68.7 & 44.6 & 124.3 & 124.3 & 60.0 \\
\hline Total with up & 840.6 & 328.2 & 201.7 & 113.3 & 9354.0 & 1117.3 & 1096.2 \\
\hline Total with he & 854.1 & 271.8 & 183.6 & 110.8 & 7751.0 & 1119.5 & 880.6 \\
\hline
\end{tabular}

Table 2 shows the scattered radiation doses to hands, genitals, eye lens and neck of the radiographer and assisting personnel, derived from doses measured for different views at 
different measurement points. During five measurements of the background, with the measurement duration ranging from 5 to $45 \mathrm{~min}$, the values of 90 - $108 \mathrm{nGy} / \mathrm{h}$ were obtained. Due to the fact that the exposure time during the proper measurements of scattered radiation doses for different views was $0.06-0.12 \mathrm{~s}$ and the values obtained were immediately read on the display of the apparatus, they were not corrected for the background. Because the radiation weight factor for $\mathrm{X}$-ray radiation equals to 1 , we can regard the scattered radiation values measured as equivalent doses. The equivalent doses that the radiographer and the assisting personnel would receive during the entire radiological examination of the distal interphalangeal joint are given in Table 3. Table 3 lists equivalent doses received by the personnel during examination of the distal interphalangeal joint both on LM, PP-PD, DP-PDup, DL-PMup and DM-PLup views and LM, PP-PD and DP-PDhc, DL-PMhc and DM-PLhc views.

Table 3. Scattered radiation doses (in $\mathrm{nSv}$ ) received by the radiographer and assistants to selected organs and tissues during the entire radiography of distal interphalangeal joint

\begin{tabular}{|l|c|c|c|c|c|c|}
\hline \multirow{2}{*}{ Organ } & \multicolumn{2}{|c|}{ Radiographer } & \multicolumn{2}{c|}{ Assistant - cassette } & \multicolumn{2}{c|}{ Assistant - limb } \\
\cline { 2 - 7 } & UP & HC & UP & HC & UP & HC \\
\hline Hands & 846.6 & 854.1 & 201.7 & 183.6 & 9354.0 & 7751.0 \\
\hline Genitals & 846.6 & 854.1 & 201.7 & 183.6 & 1117.3 & 1119.5 \\
\hline Eye lens & 328.2 & 271.8 & 113.3 & 110.8 & 1096.2 & 880.6 \\
\hline Neck & 328.2 & 271.8 & 113.3 & 110.8 & 1096.2 & 880.6 \\
\hline $1 \mathrm{~cm}^{2}$ of skin & 587.4 & 563.0 & 157.5 & 147.2 & 3165.9 & 2657.9 \\
\hline
\end{tabular}

The data obtained in the present study showed that the assistant holding the cassette behind the examined region received the lowest dose of scattered radiation during radiography of the distal interphalangeal joint; the radiographer received a higher dose and the assistant performing positioning of the examined limb received the highest dose of radiation. The differences between radiation doses were statistically significant $(p<0.05)$. The values obtained also showed that the doses of scattered radiation received by the assistant holding the cassette and the radiographer were similar to those received during examination of the distal interphalangeal joint on views with a raised limb placed on the navicular block and during examination of the distal interphalangeal joint on views with the weight bearing limb placed on a pedestal. Exposure to scattered radiation by the assistant positioning the limb was higher when the radiological examination of the distal interphalangeal joint was performed on views with a raised limb placed on a navicular block. The difference between exposure doses was not statistically significant, which may be due to low numbers of the data compared.

Comparison of equivalent doses to the hands, eye lenses and $1 \mathrm{~cm}^{2}$ of skin of the radiographer and assisting personnel, as measured during X-ray examination of the equine distal interphalangeal joint, revealed that it is practically impossible for these people to perform so many radiological examinations during one year and not to exceed the limits.

\section{Discussion}

It is generally known that any exposure to ionizing radiation is dangerous. Therefore, it is not possible to set a limit that would fully protect tissues. The dose limits have been adopted with an aim to completely prevent deterministic (non-stochastic) effects and minimize potential development of stochastic effects due to doses acceptable for individuals and the general public. In contrast to deterministic effects, a threshold has not been defined for the stochastic effect, the exceeding of which would bring about the manifestation of the effects. The results we have received showed that the assistant holding the cassette behind the 
examined region received the lowest dose of scattered radiation during radiography of the distal interphalangeal joint. This can be explained by his distance from the source of scattered radiation and by the fact that a part of scattered radiation was absorbed by the cassette and the holder. The exposure of the assistant to scattered radiation was similar to that during examination of the distal interphalangeal joint on LM, PP-PD, DP-PDup, DL-PMup and DM-PLup views and during examination of the distal interphalangeal joint on LM, PP-PD, DP-PDhc, DL-PMhc and DM-PLhc views. The obtained data showed that the radiographer was exposed to higher doses of scattered radiation; he was in a greater distance from the source of scattered radiation, however, he was not shielded at all. Exposure of the radiographer to scattered radiation was similar to that during examination of the distal interphalangeal joint on LM, PP-PD, DP-PDup, DL-PMup and DM- PLup views and during examination of the distal interphalangeal joint on LM, PP-PD, DP-PDhc, DL-PMhc, DM-PLhc views. When the radiological examination was performed on LM, PP-PD, DP-PDup, DL-PMup and DM-PLup views, he received higher doses.

The measured values of equivalent doses received by the radiographer and his assistants during radiological examination of the distal interphalangeal joint detected in the present study appear to be very low, in comparison with the limits. However, we should keep in mind that particularly the personnel involved in radiological examinations are also exposed to scattered radiation during other examinations when they are often exposed to much higher doses. Therefore, all the possibilities to decrease exposure time of personnel during any radiological examination, i.e. also during examination of the distal interphalangeal joint, should be made use of. It is well known that reduced exposure time, increased distance from the radiation source and the use barriers may protect from ionizing radiation. However, exposure time cannot be shortened during radiological examination of the distal interphalangeal joint; the exposure time values have been set and if they are not observed, the radiograph is damaged. Protection by increased distance from the radiation source cannot be applied for the radiographer who runs the X-ray machine during exposure and prevents its damage by the examined horse. It is possible to apply this protection for the assistant holding the cassette behind the examined region by increased distance using a holder with an appropriately long handgrip. It is also possible to apply this type of protection for the assistant holding the limb, by increasing the distance during radiological examination of the distal interphalangeal joint on DP-PD, DL-PM and DM- PL views of a weight bearing limb placed on a pedestal. The protection of all persons exposed to scattered radiation during the radiological examination must be increased by using barriers such as protective aprons, gloves and collars.

\section{Expozice personálu rozptýleným zářením během rentgenologického vyšetření kopytního kloubu u koně přenosným rentgenovým přístrojem}

V naší studii bylo prováděno rentgenologické vyšetření kopytního kloubu na dvou končetinách, získaných z kadáveru koně o hmotnosti $550 \mathrm{~kg}$. Vyšetření bylo prováděno v lateromediální, palmaroproximálně-palmarodistální projekci a v dorzoproximálněpalmarodistálních, dorzolaterálně-palmaromediálních, dorzomediálně-palmarolaterálních projekcích, na zvednuté končetině umístěné ve střelkovém bloku a na zatížené končetině. Během tohoto vyšetření byly měřeny dávky rozptýleného záření na místech rentgenologa, asistenta přidržujícího kazetu $s$ filmem a na místě asistenta fixujícího vyšetřovanou končetinu nebo protilehlou končetinu. Měřením bylo zjištěno, že nejnižší expozici rozptýleným zářením byl vystaven asistent přidržující kazetu za vyšetřovanou krajinou, který obdržel během celého vyšetření kopytního kloubu ekvivalentní dávku na ruce a gonády 183,6 - 201,7 nSv a ekvivalentní dávku na oční čočku a krk 110,8 - 113,3 nSv. Vyšší expozici byl vystaven rentgenolog, který obdržel ekvivalentní dávku na ruce a gonády 
846,6 - 854,1 nSv a ekvivalentní dávku na oční čočku a krk 271,8 - 328,2 nSv. Nejvyšší expozici rozptýleným zářením byl vystaven asistent fixující končetinu, který obdržel ekvivalentní dávku na ruce 7751 - 9354 nSv, ekvivalentní dávku na gonády 1117,3 - 1119,5 nSv a ekvivalentní dávku na oční čočku a krk 880,6 - 1096,2 nSv. Tyto naměřené hodnoty ekvivalentních dávek, které obdrží rentgenolog a jeho asistenti během vyšetření kopytního kloubu, se jeví při srovnání s limity ozáření př́liš nízké. Je však nutné si uvědomit, že zejména radiační pracovníci jsou vystaveni expozici rozptýleným zářením i při jiných vyšetřeních, při kterých často obdrží mnohem vyšší dávky. Proto považujeme za nutné používat i během rentgenologického vyšetření kopytního kloubu ochranné zástěry, rukavice a límce.

\section{References}

BUTLER JA, COLLES CM, DYSON SJ, KOLD SE, POULOS PW 2000: Foot, Pastern and Fetlock. In: BUTLER JA, COLLES CM, DYSON SJ, KOLD SE, POULOS PW: Clinical Radiology of the Horse. London; Blackwell Science Ltd., pp. 27-130

CRHAKOVA T 2003: Application of oblique views in radiography of discrete osteoarthritic changes in distal interphalangeal joint and proximal interphalangeal joint of horse. Thesis, University of Veterinary and Pharmaceutical Sciences, Clinic for Horse Diseases.

EURATOM 1996: Council Directive 96/29/Euratom of 13 May 1996 laying down basic safety standards for the protection of the health of workers and the general public against the Langer arising from ionizing radiation. Official Journal of the European Communities 39

ICRP Publication 60: 1990: Recommendations of the international commission on radiographic protection. Ann ICRP 21:1-3

KAWCAK CHE 2001: Current and future diagnostic means to better characterize osteoarthritis in the horseimaging. AAEP Proceedings 47: 164-170

LAUK HD 2002: Pre-purchase examination - a constant challenge. Do we need a widened standard? (in German). Pferdeheilkunde 18: 212-216

LAVIN LM 1999: Radiation safety. In: LAVIN LM: Radiography in veterinary Technology. Philadelphia; W.B. Saunders, pp. 21-40

MORGAN JP, NEVES J, BAKER T 1991: Digit. In: MORGAN JP, NEVES J, BAKER T: Equine Radiography. Ames, Iowa; Iowa State University Press, pp. 45-52

NOLKER A, UELTSCHI G 2001: Scattering ray exposure of personnel during veterinary X-ray examinations with the C-bow-technique. Tieraerztl Umschau 56: 519-527

STASHAK TS 2002: Lameness; Part I: The Foot, and Part II: The Pastern. In: STASHAK TS ADAMS': Lameness in horses. Philadelphia; Lippincott Williams and Wilkins, pp. 645-767

UELTSCHI G 2002: Radiography of the navicular bone. Pferdeheilkunde 18: 217-224

Vyhláška Státního úřadu pro jadernou bezpečnost č. 307 ze dne 13. června 2002 o radiační ochraně. Sbírka zákonů České republiky, ročník 2002, částka 113 


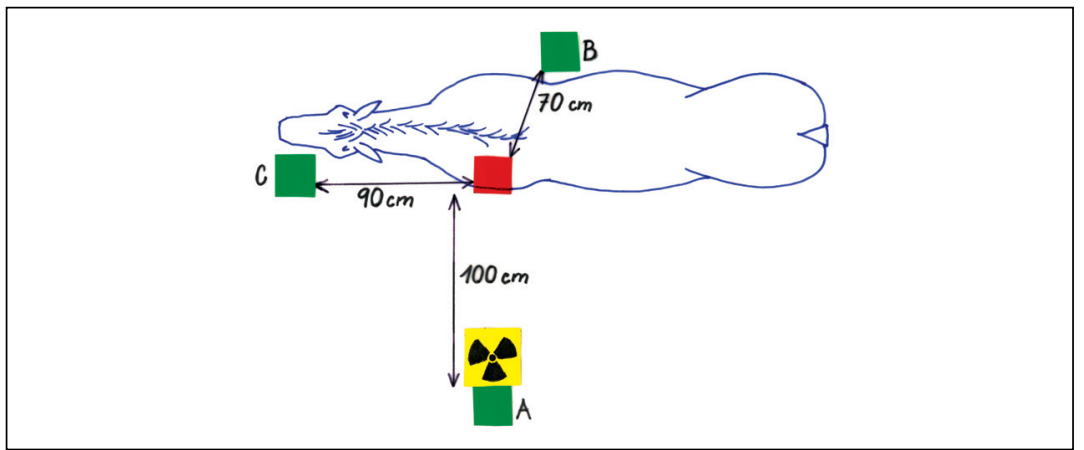

Fig. 1. Positions of the X-ray machine, examined limb and measurement points during the radiological examination of distal interphalangeal joint on LM view

$\mathrm{A}=$ position of the radiographer behind the $\mathrm{X}$-ray machine, $\mathrm{B}=$ position of the assistant positioning the horse's limb, $\mathrm{C}=$ position of the assistant positioning the cassette.

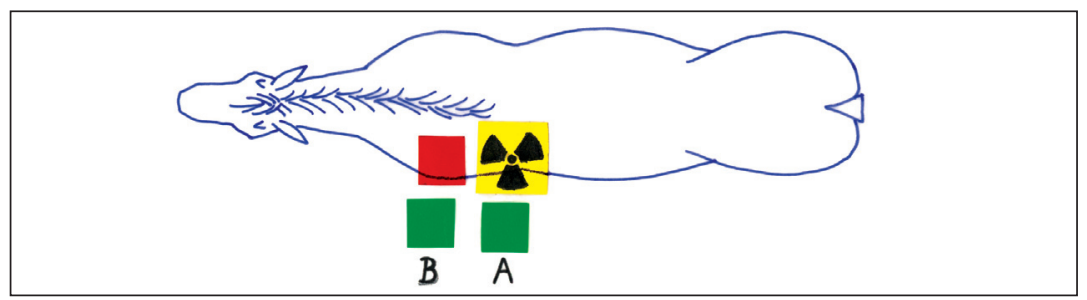

Fig. 2. Positions of the X-ray machine, examined limb and measurement points during the radiological examination of distal interphalangeal joint on PP-PD view

$\mathrm{A}=$ position of the radiographer behind the $\mathrm{X}$-ray machine, $\mathrm{B}=$ position of the assistant positioning the horse's limb.

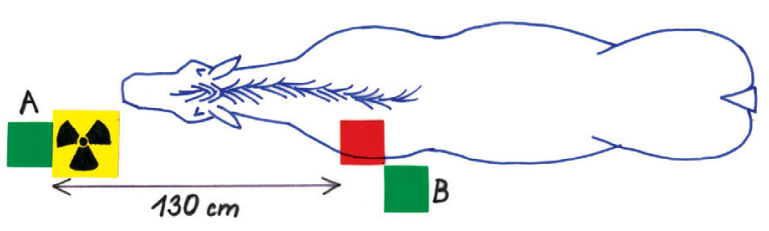

Fig. 3. Positions of the X-ray machine, examined limb and measurement points during the radiological examination of distal interphalangeal joint on DP-PDup view

$\mathrm{A}=$ position of the radiographer behind the $\mathrm{X}$-ray machine, $\mathrm{B}=$ position of the assistant positioning the horse's limb.

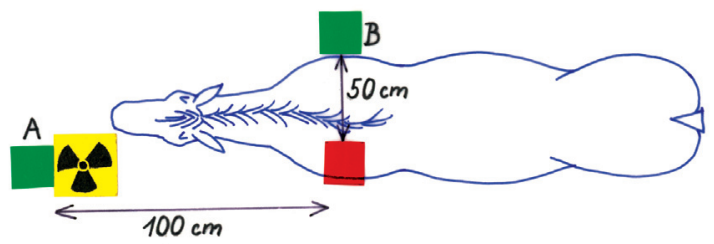

Fig. 4. Positions of the X-ray machine, examined limb and measurement points during the radiological examination of distal interphalangeal joint on DP-PDhc view $\mathrm{A}=$ position of the radiographer behind the $\mathrm{X}$-ray machine, $\mathrm{B}=$ position of the assistant positioning the horse's limb. 


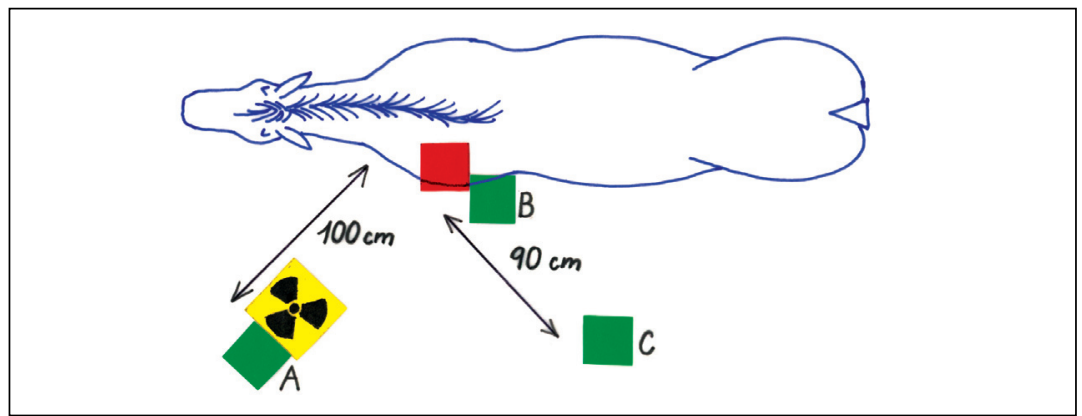

Fig. 5. Positions of the X-ray machine, examined limb and measurement points during the radiological examination of distal interphalangeal joint on DL-PMup view $\mathrm{A}=$ position of the radiographer behind the $\mathrm{X}$-ray machine, $\mathrm{B}=$ position of the assistant positioning the horse's limb, $\mathrm{C}=$ position of the assistant holding the cassette.

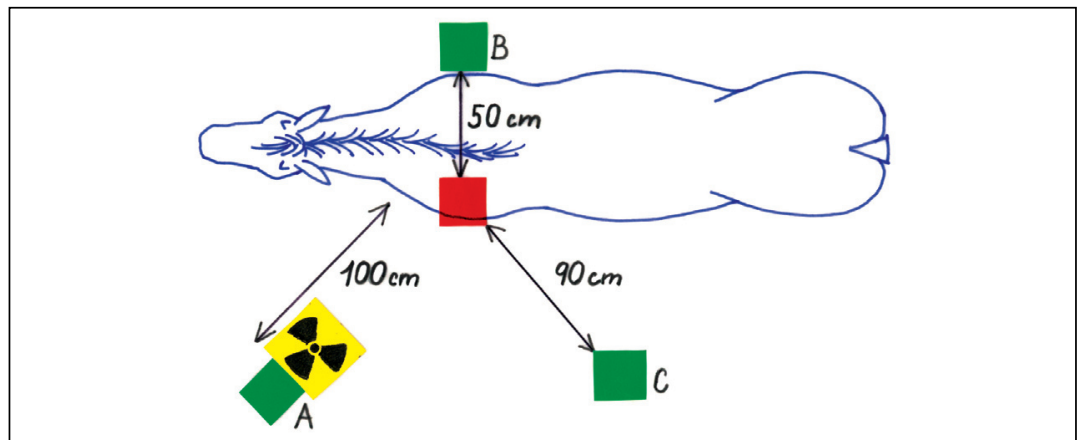

Fig. 6. Positions of the X-ray machine, examined limb and measurement points during the radiological examination of distal interphalangeal joint on DL-PMhc view $\mathrm{A}=$ position of the radiographer behind the $\mathrm{X}$-ray machine, $\mathrm{B}=$ position of the assistant positioning the horse's limb, $\mathrm{C}=$ position of the assistant holding the cassette.

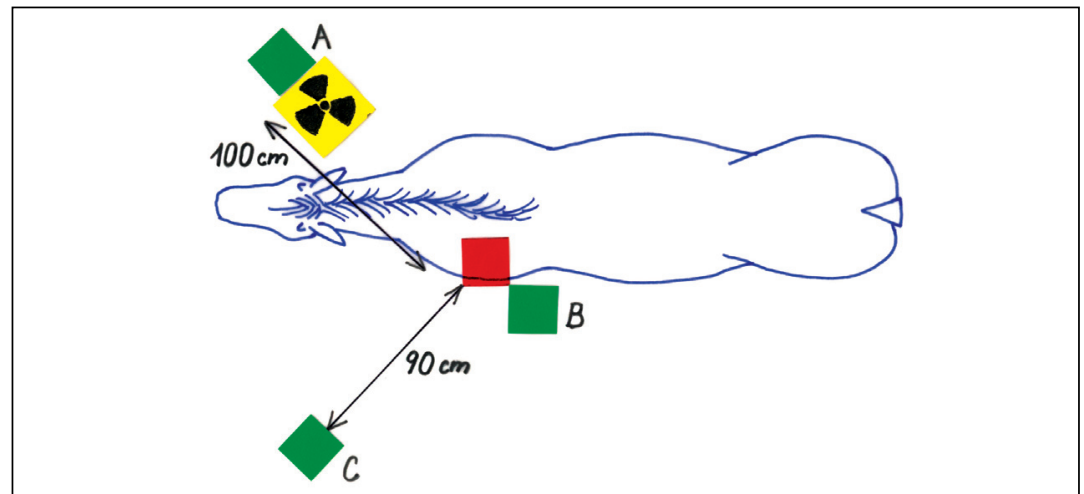

Fig. 7. Positions of the X-ray machine, examined limb and measurement points during the radiological examination of distal interphalangeal joint on DM-PLup view $\mathrm{A}=$ position of the radiographer behind the $\mathrm{X}$-ray machine, $\mathrm{B}=$ position of the assistant positioning the horse's limb, $\mathrm{C}=$ position of the assistant holding the cassette. 


\section{Plate X}

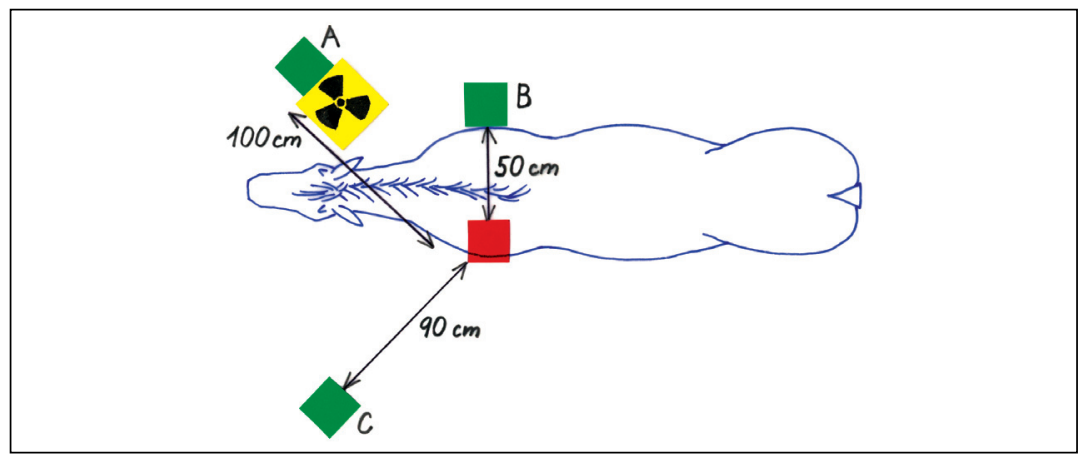

Fig. 8. Positions of the X-ray machine, examined limb and measurement points during the radiological examination of distal interphalangeal joint on DM-PLup view

$\mathrm{A}=$ position of the radiographer behind the $\mathrm{X}$-ray machine, $\mathrm{B}=$ position of the assistant positioning the horse's limb, $\mathrm{C}=$ position of the assistant holding the cassette.

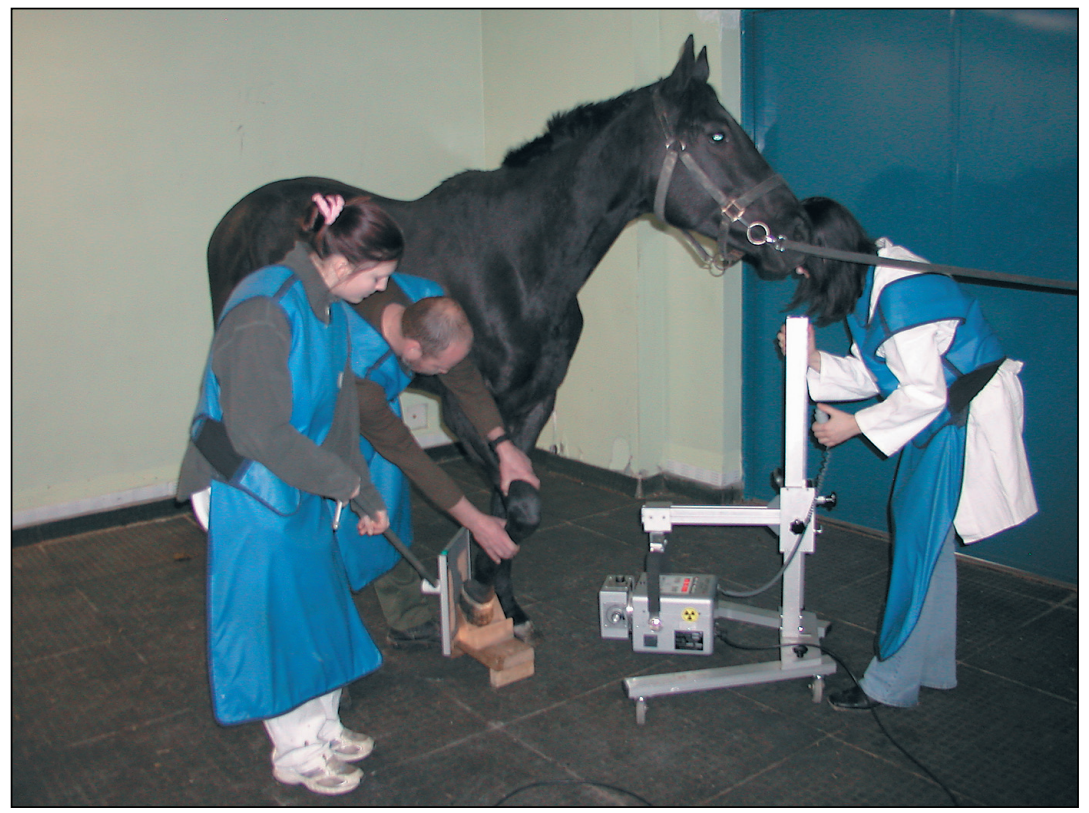

Fig. 9. Positions of the radiographer and assistants during the radiological examination of distal interphalangeal joint on DM-PLup view. 


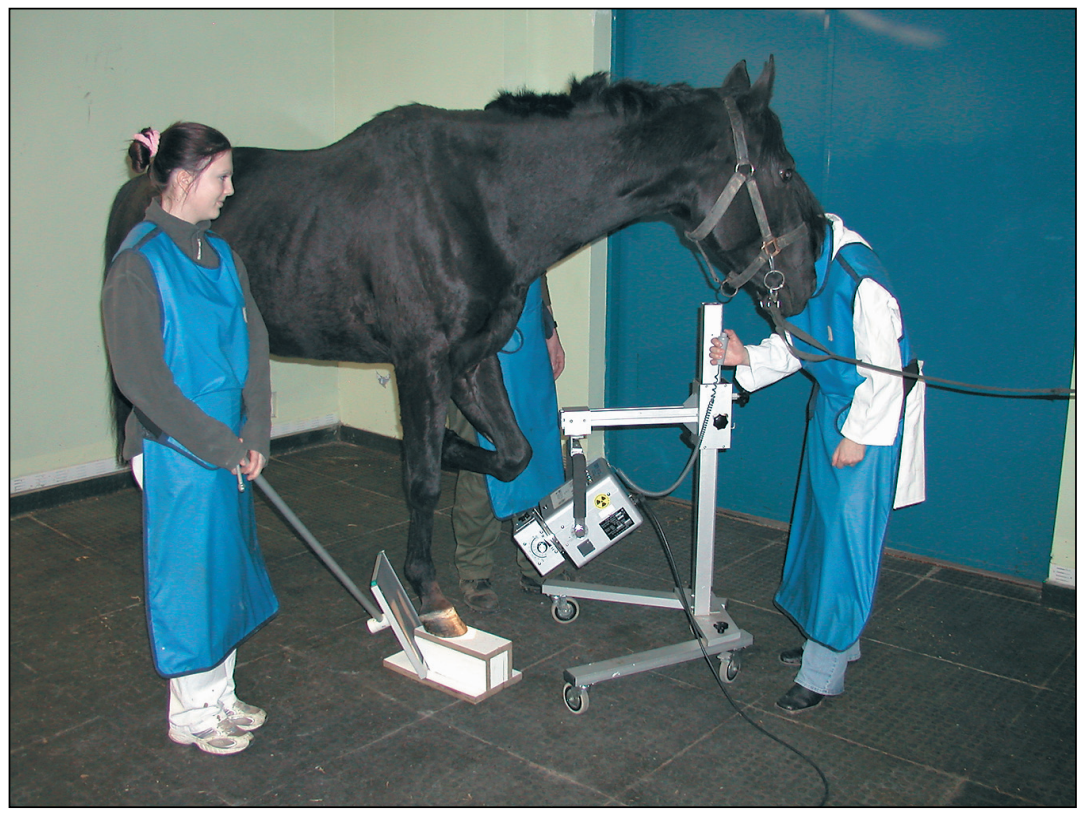

Fig. 10. Positions of the radiographer and assistants during the radiological examination of distal interphalangeal joint on DM-PLhc view. 